International Journal of Current Advanced Research

ISSN: O: 2319-6475, ISSN: P: 2319 - 6505, Impact Factor: SJIF: 5.995

Available Online at www.journalijcar.org

Volume 6; Issue 4; April 2017; Page No. 3180-3181

DOI: http://dx.doi.org/10.24327/ijcar.2017.3181.0218

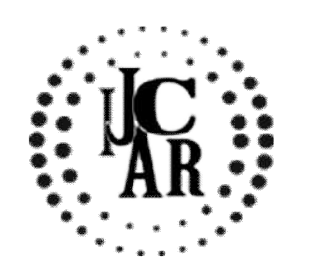

Research Article

\title{
EFFECT OF RESPIRATORY PROBLEM ONC-SECTION AND VAGINAL BIRTH
}

\author{
Saranya.M and Gayatri Devi
}

Saveetha Dental College and Hospitals, Chennai-600 077

\begin{tabular}{l}
\hline A R T I C L E I N F O \\
Article History: \\
Received $11^{\text {th }}$ January, 2017 \\
Received in revised form $19^{\text {th }}$ February, 2017 \\
Accepted $22^{\text {nd }}$ March, 2017 \\
Published online $28^{\text {th }}$ April, 2017 \\
\hline
\end{tabular}

Key words:

Vaginal birth, episiotomy,

respiratory distress syndrome,

\begin{abstract}
A B S T T R A C T
Aim: An aim on effects of respiratory problem on C -section and Vaginal birth

Objective: Since the risk of respiratory problem is higher in C-section than in vaginal birth.

Background: C-section does pose higher risk of complications than vaginal birth.The complications are heavy blood loss, infection and bowel problems, where as, in vaginal birth carries a risk of episiotomy. It is generally painful and messy. It is usually hard work and women often perspire heavily. There are other body fluids too-amniotic fluid, urine and blood - there is placenta (after birth).

Reasons: Now a days, C-section is very common when compared to vaginal birth. The risk of respiratory problem is higher in $\mathrm{C}$-section than in vaginal birth.
\end{abstract}

Copyright $₫ 2017$ Saranya.M and Gayatri Devi. This is an open access article distributed under the Creative Commons Attribution License, which permits unrestricted use, distribution, and reproduction in any medium, provided the original work is properly cited.

\section{INTRODUCTION}

Pregnancy is done in two ways: Pregnant women can either have a vaginal birth or surgical delivery by $\mathrm{C}$-section but their goal is to safely give birth to a healthy baby. Generally, babies born by $\mathrm{C}$-section poses several challenges when compared to babies born through vaginal birth. Babies born through cesarean are at higher risk of health complications and they are less likely to face with a normal birth.If the mother is not under going through labor pain, babies are more likely to have difficulty breathing on their own ${ }^{[2]}$. Respiratory complicated babies are generally treated with special care nursery ${ }^{[2] .}$ The caesarean children are at an increased risk of developing asthma because of the intestinal bacteria ${ }^{[2]}$. Breathing problems can also lead to Respiratory Distress Syndrome (RDS) which is due to lack of surfactant in lungs and expansion of lung is not great. These babies are hospitalised for about 25.7 days. They are kept in neonatal intensive care unit (NICU). Cesarean babies are less likely to have skin to skin contact immediately after birth with their mother ${ }^{[2]}$. Atopic diseases also appear more often in infants after caesarean delivery than after vaginal delivery. ${ }^{[1]}$

The most safest way for giving birth to a baby is through vaginally. Because they have lower risk of respiratory problems. ${ }^{[3]}$ It decreases the risk of immune system disorders such as asthma and allergies ${ }^{[5]}$.During the birth process, the amniotic fluid is expelled by the compression of the baby's thorax and helps to prepare the lungs to breathe air.

*Corresponding author: Saranya.M

Saveetha Dental College and Hospitals, Chennai-600 077
The advantage of having vaginal birth is that the baby can soon have breastfeeding. ${ }^{[3]}$ Gut bacteria is another advantage for the vaginal babies, it plays an important role in sustaining strong immune system and proper digestion. In the placenta and umbilical cord, hormone called endorphins is found which helps the baby adjust to life outside the womb. ${ }^{[6]}$ The risk of Type 1 diabetes is $20 \%$ is lower in vaginal birth babies $^{[3]}$. Very rarely the the vaginal birth babies are kept in Neonatal Intensive Care Unit(NICU). Therefore, vaginal birth babies do not experience much side effects. ${ }^{[3]}$

\section{MATERIALS AND METHOD}

The study was done in a Chennai private hospital. The study was done with 50 babies. Out of which 15 babies were born through $\mathrm{C}$ section, 15 babies were born vaginally and 20 babies are pre term babies.Included babies for the study are $\mathrm{C}$ section and vaginal birth babies. Excluded babies are pre term babies.

In this study the pregnancy method whether it is $\mathrm{C}$ section or vaginal birth it is recorded, the respiratory problem and complications of the baby is recorded.

\section{RESULT}

Table 1 C-section Babies

\begin{tabular}{cccc}
\hline $\begin{array}{c}\text { Total C- } \\
\text { section babies }\end{array}$ & $\begin{array}{c}\text { Respiratory problem- } \\
\text { Transient Tachypnea } \\
\text { of the New born }\end{array}$ & $\begin{array}{c}\text { Complications- } \\
\text { Respiratory } \\
\text { Distress Syndrome }\end{array}$ & $\begin{array}{c}\text { Complications- } \\
\text { Chronic } \\
\text { Asthma }\end{array}$ \\
\hline 15 & 15 & 8 & 7 \\
\hline
\end{tabular}




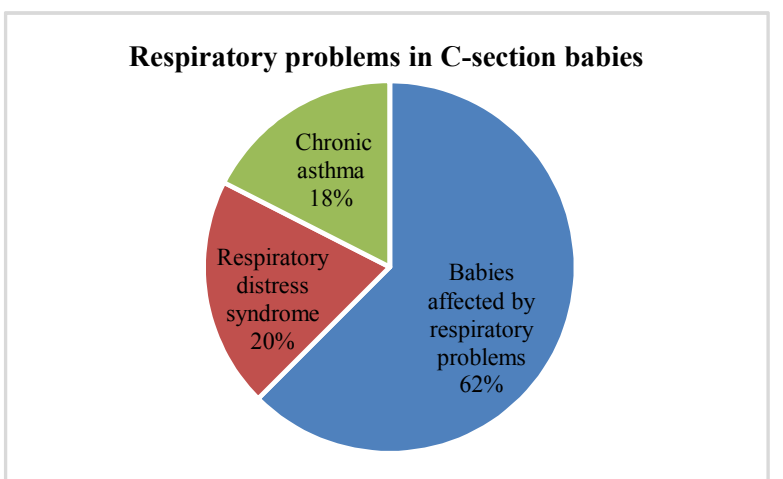

Table 2 Vaginal Birth Babies

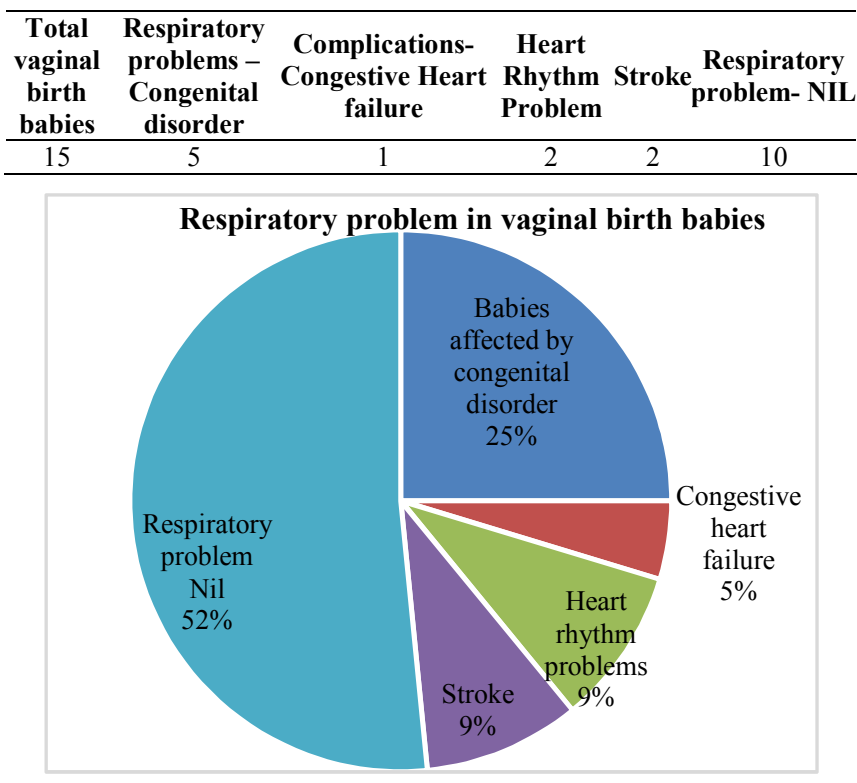

\section{DISCUSSION}

Muscles involved in the process are more likely to squeeze out the fluid found in new born babies lungs. In the study of Bryant, it is a benefit for babies which is less likely to suffer breathing problems at birth. An early dose of good bacteria as they travel through their mother's birth canal, that boost their immune system and intestinal tract is protected. The baby get injured during the birth process itself, such as having a bruised scalp or fractured collar bone, if the women is having long labor or the baby is large and delivered vaginally. ${ }^{[4]}$
$\mathrm{C}$-section delivered babies has an increased risk of becoming obese as they as children and become adults. Women who are obese or having pregnancy related diseases there is a possibility of having caesarean delivery. Each year most of the babies are delivered through caesarean, before onset of spontaneous labor.Birth asphyxia, meconium aspiration, and hypoxic ischemic encephalopathy are the complications occurs in caesarean delivery ${ }^{[1]}$.

In the present study of C-section, out of $15 \mathrm{C}$-section babies, $62 \%$ of babies are affected by respiratory problem, in that $20 \%$ are complicated by respiratory distress syndrome and $18 \%$ are complicated by chronic asthma. In present study of vaginal delivery, out of 15 babies, $52 \%$ babies does not have any respiratory problem, in that, $25 \%$ babies are affected by congenital disorder, $5 \%$ babies are complicated by congestive heart failure, $9 \%$ are complicated by heart rhythm problems and $9 \%$ are complicated by stroke.

\section{CONCLUSION}

Vaginal delivery is better than Caesarean section because it has lower risk of respiratory problems.

\section{References}

1. Elective Cesarean section: Its impact on Neonatal Respiratory outcome.

2. Ashwin Ramachandrappa, MD and Lucky Jain, MD, MBA

3. How Does a Cesarean Affect The Baby? www.vbac.com

4. Vaginal Birth Benefits. www.pregnancy-and-givingbirth.com

5. Vaginal Birth vs C-Section: Pros \& Cons.www.livescience.com

6. The Vaginal Advantage. www.fitpregnancy.com

7. 13 benefits of Natural Childbirth.www.mama natural.com

\section{How to cite this article:}

Saranya.M and Gayatri Devi (2017) ' Effect Of Respiratory Problem Onc-Section And Vaginal Birth', International Journal of Current Advanced Research, 06(04), pp. 3180-3181.

DOI: http://dx.doi.org/10.24327/ijcar.2017.3181.0218 